\title{
The Structure of Jay Gatsby's Personality in The Great Gatsby Novel
}

\author{
Nindita Ratri $^{1^{*}}$, I Gusti Agung Istri Aryani ${ }^{2}$ \\ English Department, Faculty of Arts, Udayana University \\ 1'[ditaprasodjo@gmail.com], ${ }^{2}$ [ig_aryani@yahoo.com] \\ *Corresponding Author
}

\begin{abstract}
This study entitled “The Structure of Jay Gatsby's Personality in The Great Gatsby Novel" is aimed to describe Jay Gatsby's structure of personality and his behavioral representations. The data were taken from the novelThe Great Gatsby written by F. Scott Fitzgerald. Qualitative method was applied to analyze Jay Gatsby's structure of personality and his behavioral representations. The theories used to analyzed are the theory of literature proposed by Kenney, theory of psychoanalysis and theory of anxiety proposed by Freud. The theory of literature showed that The Great Gatsby used mixed plot and in order to reveal the character of Jay Gatsby, mixing method was used.The psychoanalysis theory showed three structures of personality of human minds: the id, the ego, and the superego. The behavioral representations of the structure of personality showed in anxiety and defense mechanism of the ego: repression, fixation, and regression. The result of analysis showed that the desire of human beings must not be negative and must be realistic otherwise it will effect his/her behavior and how he/sheis treated in society.
\end{abstract}

Keywords: Personality, Behavioral representations, Ego defense mechanisms

\begin{abstract}
Abstrak
Penelitian ini bertujuan untuk menggambarkan struktur kepribadian Jay Gatsby dan representasi perilakunya. Data diambil dari novel The Great Gatsby oleh F. Scott Fitzgerald. Metode kualitatif diterapkan untuk menganalisis struktur kepribadian Jay Gatsby dan representasi perilakunya. Teori yang digunakan untuk menganalisis data adalah teori sastra yang diusulkan oleh Kenney, teori psikoanalisis dan teori kegelisahan yang diusulkan oleh Freud. Teori sastra menunjukkan bahwa novel The Great Gatsby menggunakan alur campuran dan metode campuran digunakan untuk menunjukkan karakter Jay Gatsby. Teori psikoanalisis menunjukkan tiga struktur kepribadian manusia: id, ego, dan superego. Representasi perilaku dari struktur kepribadian menunjukkan adanya kegelisahan dan mekanisme perlindungan ego yang terdiri dari: pengekangan, fiksasi, dan regresi. Hasil dari analisis menunjukkan bahwa keinginan manusia tidak boleh negatif dan harus realistis karena itu akan berimbas kepada perilaku manusia tersebut dan bagaimana ia diperlakukan di masyarakat.
\end{abstract}

Kata kunci: Kepribadian, Representasi perilaku, Mekanisme perlindungan ego 


\section{Background of the Study}

Imagination plays an important role in creating an interesting literary work. Imagination of the writers generally reflects the condition or the environment surrounding them, then the writers use their words to create the story on the literary works using characters. The relation between characters in the story and the readers is a big deal, because they perceive the characters as a depiction of real human beings in real life. Therefore, it is important to do this study in order to figure out how we see ourselves, what motivates us, what makes us feel and act in certain ways by studying the characters, in hopes of a better understanding of human nature and selfknowledge.

This study uses the novel The Great Gatsby by F. Scott Fitzgerald. This novel was chosen because one of the main characters, Jay Gatsby, is a perfect example of a human trying to satisfy his inner desire by acting in certain ways. The study revolves around the life of Jay Gatsby which is driven by his passion, lust and obsession towards Daisy Buchanan. Through this study, a full understanding of Jay Gatsby's personality is made possible to learn more about human minds.

\section{Problems of the Study}

a. What are Jay Gatsby's structure of personality in the novel The Great Gatsby by F. Scott Fitzgerald?

b. What are the behavioral representations of Jay Gatsby's structure of personality in the novel The Great Gatsby by F. Scott Fitzgerald?

\section{Aims of the Study}

a. To describe Jay Gatsby's structure of personality in the novel The Great Gatsby. b. To describe the behavioral representations of Jay Gatsby's structure of personality in the novel The Great Gatsby.

\section{Research Method}

This study used qualitative method. Qualitative method involves an interactive process in which the persons/objects studied teach the researcher about their lives. Because statistics are not used, but rather uses a more descriptive, narrative style, this method is useful in language research.

\subsection{Data Source}

The data in this study were taken from the novel entitled The Great Gatsby by F. Scott Fitzgerald (1925). In The Great Gatsby, Jay Gatsby is showed as a complicated, mysterious character trying to satisfy his inner desire to recapture the past with his old lover, Daisy Buchanan. This novel was chosen because it is important to learn how one's mind and personality works within oneself, and to value oneself as an individual within a society by analyzing Jay Gatsby's structure of personality and its behavioral representations.

\subsection{Method and Technique of Collecting Data}

In attempting to find the data, documentation method was applied in this study, which the following steps: reading the novel to find the issues regarding Jay Gatsby's characters. Then, taking some notes regarding Jay Gatsby's character manifestations in his behavior.

\subsection{Method and Technique of Analyzing Data \\ The data were analyzed using} qualitative method. The technique of analyzing data was done in three steps. First, analyzing the plot of The Great 
Gatsby and characters of Jay Gatsby based on the theory proposed by Kenney (1966). Second, analyzing Jay Gatsby's structure of personality using Freud's theory of psychoanalysis (1923). The next step was to analyze Jay Gatsby's behavioral representations using thetheory of anxiety proposed by Freud (1949).

\subsection{Method and Technique of Presenting Analysis}

The data are presented with informal method.First, the data were classified with each plot structure along with the explanation about the situations and the emphazised statements. Next, the data were described accordingly based on each character presental methods. Then, the analysis of Jay Gatsby's structure of personality was described withthe classification of id, ego and superego. Finally, the behavioral representations of Jay Gatsby's structure of personality was analyzed with the classification of anxiety and defense mechanism of the ego.

\section{Result and Discussion}

\subsection{Plot}

In The Great Gatsby mixed plot was used, where the story is told in order which it occured mixed along with the flashbacks showed in between.

\subsection{Character}

The mixing method was used to reveal Jay Gatsby's characters. In the beginning of the story, Gatsby was established as a dreamer who was macho, charming, gracious, and a bit mysterious. Gatsby was, in many ways, some of the things he stood for might not be so admirable, as shown in the statement "as obscurely as it had begun" (Chapter 7:71). The statement "so he invented just the sort of Jay Gatsby" (Chapter 6:63) showed his plan of inventing a new identity, character and personality.He believed in the American Dream, that one really could work one's way up through hard work, resolve, and selfcontrol.Gatsby had always been very diligent and detail-oriented. Ever since he was a little kid, he had had a plan for his life. In a book he had as a child, he wrote a schedule for his day detailing what he was going to do (Chapter 9:110).

By being so focused on his dream of Daisy, Gatsby moved further and further into a fantasy world, which had become a childish illusion. His inability to deal with reality set him outside the norm as seen in the statement "you don't understand', with a touch of panic. 'You're not going to take care of her any more" (Chapter 7:85). He was completely unable to realize that his dream was not a reality.He saw what he was doing as noble, honorable, and purposeful, while in reality, he was very delusional as shown in the statement "I want to wait here till Daisy goes to bed" (Chapter 7:93).

\subsection{Jay Gatsby's Structure of Personality}

In Gatsby's case, his unconscious mind leads him towards something that he can never have, but wants so badly; he is driven by his desire for Daisy Buchanan on the id level.When Gatsby first met Daisy, he was instantly attracted to her, because not only was she beautiful but she was incredibly wealthy as well. He was still poor and he knew that she would never look at a man like him, let alone love him. So, in Gatsby's mind, his id told him to chase Daisy. He would do whatever it took to have Daisy in his arms, so he lied to her that he was also rich and from the same social strata as her, as shown in the following data in the 
statement "he let her believe that he was a person from much the same strata as herself" (Chapter 8:95).However, that did not last long since Gatsby had to leave for war, eventually telling Daisy about his true background, that he was just a penniless man, in other words, poor. That news upset her and she then moved on to another man in her life, eventually marrying him, resulting in Gatsby's id being repressed.

In order to fulfill his id's repressed desire, his ego supported it by making a plan to reach that satisfaction. That was when Gatsby found out that his next door neighbor, Nick Carraway, was Daisy's cousin. So he tried to befriend Nick, eventually telling him to make a surprise reunion betwen Daisy and Gatsby. And so, their relationship bloomed once more and his id was then fulfilled again. His ego then escalated into a higher desire of wanting Daisy to leave Tom as seen in the statement "she should go to Tom and say: 'I never loved you" (Chapter 6:70) when he was talking to Nick. He told her to say a few things to Tom, that she never loved him and that she was leaving him. Ofcourse those things were not true, because Daisy loved Tom when she married him, and she did not want to leave him.

In The Great Gatsby, his superego camein many shapes. Nick Carraway often became his advisor that he could not repeat the past, that he should move on. The statement "you can't repeat the past" (Chapter 6:70) showed that Nick tried to warn Gatsby that he could not repeat the past and that he should move on and let Daisy go.

\subsection{Behavioral Representations}

Jay Gatsby displayed two behavior types, they are classified as anxiety and defense mechanism of the ego.

\subsubsection{Anxiety}

This behavior usually appeared every time superego prevented him from fulfilling his id, which made him very anxious or nervous, in fear of unsatisfied needs or desire. The statement "I wanted somebody who wouldn't gossip." (Chapter 7:71) showed that Gatsby was experiencing anxiety, where he thought that his affair with Daisy had gone too far, and everybody started to notice that. The statement "I don't want you to get a wrong idea of me from all these stories you hear" (Chapter 4:42) showed that Gatsby was experiencing anxiety because he was aware about the suspiciousness and the bad rumors floating around about him, and he was trying to set the record to Nick about his background, which was just a cover up of his lie.The statement "looking at me with suppressed eagerness" (Chapter 5:52) showed that Gatsby was holding back his anxiety when he showed up at Nick's house one night, waiting for him to come home. He was very anxious of hearing if Nick agreed to make a reunion for him and Daisy.The statement "with a touch of panic" (Chapter 7:85) showed that he started panicking when Daisy chose her husband, and backed away from leaving him. He then mumbled out his defenses when Tom confronted him about his illegal bootleg business, and started speaking nonsense to Daisy when she finally learned his real identity, which Nick explained in the statement "he looked, as if he had 'killed a man"" (Chapter 7:85). The statement "he asked anxiously" (Chapter 7:93) showed that Gatsby was still panicking after he dropped Daisy off at her house which happened after his confrontation with Tom. Despite what happened at the confrontation, that Daisy chose Tom over him, he was still anxious and waited for her to come out of the house and run 
away with him, of which the event never ever happened.

\subsubsection{Defense Mechanism of the Ego}

In Gatsby's case, he did just about anything to avoid pain and preserved a sense of self, and this compulsion often resulted in him creating pyschological defenses. Jay Gatsby was showing three types of defense mechanisms of the ego; theywere repression, fixation and regression.

The statement "so he invented just the sort of Jay Gatsby" (Chapter 6:63) showed that James Gatz was so poor, he invented his new identity as Jay Gatsby, because he was trying to repress his situation back when he was still a poor kid in Minnesota. As Gatsby traded his old self for a new one, his old past became repressed and buried in the back of his mind showed in the statement "and to this conception he was faithful to the end" (Chapter 6:63).

Because Gatsby lost Daisy as he left for war, he experienced fixation when he returned, knowing that Daisy married Tom Buchanan. The statement "way off my ambitions, getting deeper in love every minute" (Chapter 8:95) showed how Gatsby was infatuated with Daisy when he was recalling his past moments to Nick. However, what he was falling for was his idea of Daisy, and this ideal image he created of Daisy stopped him from falling in love with the current Daisy or even other women. Though Daisy was married, Gatsby was still fixed on being with her.

In Gatsby's case, his regression could be recognized when he was stuck in a frustrating situation act and reacted in an immature and outworn manner. The statement " "she never loved you, do you hear?' He cried" (Chapter 7:83) showed that Gatsby was freaking out during the hotel room confrontation between him and Tom Buchanan. Like a child, he cried and was impatiently trying to make everyone in the room believe that Daisy was still in love with him by saying his thoughts out loudly and excitedly, as seen in the statement "in her heart she never loved anyone except me!" (Chapter $7: 83$ ). He thought by behaving this way, he would get what he wanted.

\section{Conclusions}

It was discovered that there are 36 data analyzed, which contained Jay Gatsby's characters and the manifestations of his behavior. From the analysis, The Great Gatsby used mixed plot and Jay Gatsby's characters were mysterious, dreamer, diligent, passionate, determined, childish and delusional. Using psychoanalysis theory proposed by Freud, it was found that the structure of personality consisted of the id, the ego, and the superego.At the level of id, Gatsby developed a desire that needed to be fulfilled by recreating the past with his old lover. He attempted to fulfill it with his ego by creating an affair with her and forcing her to leave her husband. When his superego told him that it was wrong, he developed behavioral changes.The anxiety theory by Freud was applied to analyze his behavioral changes, he developed several anxieties represented in his behavior, such as experiencing real anxiety by shutting himself off from society and neurotic anxiety by losing control of his ego, feeling overly nervous and panicking a lot. From there, his mind created a defense mechanism to protect his pride or ego by repressing his childhood and original identity, and then fixating or obsessing his unfulfilled id even more, which caused to him to regress, by being in denial and acting like a child. From this analysis, the point taken is that the id must also be realistic and not negative, otherwise it will effect 
not only one's behavior in the society, but also one's future, just as seen in Jay Gatsby's behavior.

\section{References}

Fitzgerald, F.Scott. 1925. The Great Gatsby. United States: Charles Scribner's Sons.

Freud, Sigmund. 1923. The Ego and the Id. Vienna: W. W. Norton \& Company.

Freud, Sigmund. 1949. Inhibitions, Symptoms and Anxiety (3rd Impression). London: Hogarth Press.

Kenney, William. 1966. How to Analyze Fiction. New York: Monarch Press. 